\title{
Yansıma Sözcükler ve Dilin Nedensizlik İlkesi
}

\author{
Mirfarid RZAYEV ${ }^{*}$
}

\author{
Makale Bilgisi \\ Makalenin Türü: Araştırma makalesi \\ Makalenin Geliş Tarihi: 05.11.2021 \\ Makalenin Kabul Tarihi: 22.12.2021 \\ DOI: $10.54970 /$ turkuaz.1019374
}

\section{ÖZET}

Gösteren ile gösterilen arasında bağ dilbilimde nedensizdir. Yansıma sözcükler ise bu duruma istisna olarak gösterilebilir. Yansıma sözcükler belirli kurallar çerçevesinde doğan, doğanın sesini dile aktaran bir yöntemdir. Bu sözcüklerin nedenli veya nedensiz olması tartışması uzun zamandır devam etmekte; yansıma sözcükler bazı dilbilimciler tarafından nedenli olarak görülürken bazı dilbilimciler tarafından nedensiz olarak görülmekte yani yansıma sözcüklerin gösteren ile gösterileni arasındaki bağının olmadığı bildirilmektedir. Yansıma sözcükler dünya dillerinin ve dil gruplarının hepsinde görülmektedir. Dillerde ve lehçelerde olan yansıma sözcükler aynı nedenle doğsalar bile dillerde hatta lehçelerde bile farklılık gösterebilmektedir. Türk lehçelerinde bu durum lehçeler birbirlerinden uzaklaştıkça görülmektedir. $\mathrm{Bu}$ da yansıma sözcüklerin nedenli veya nedensiz olması tartışmasını bir daha göz önünde bulundurmamıza neden olmaktadır. Asıl gerçeğe baktığımız zaman yansıma sözcükler aynı nedenden doğsalar bile her dilin ve lehçenin kendi kültürüne, tarihine, oluşumuna, dil dışı etkilere, en önemlisi ise nesilden nesle aktarımda kültürün ve tarihin derin noktalarına kazınarak değișim göstermektedir. Türk kültürünün en önemli eserlerinden biri olan Dîvânu Lugâti't-Türk'teki yansıma sözcükler de aynı şekilde nesilden nesle aktarılırken bazı küçük değişimlere uğramıștır. Dîvânu Lugâti't-Türk'te yer alan yansıma sözcükleri Oğuz grubu Türk lehçeleri ile karşılaştırdığımız zaman çok da büyük değişikliklere uğramadığını görebiliriz. Değişen yansıma sözcüklerin bir kısmı tamamen farklı adlandırılırken bir kısmı da lehçelerin kendi oluşumlarına göre uyuma girmiştir.

Anahtar Kelimeler: Yansıma sözcükler, dilin nedensizlik ilkesi, yansıma, nedenlilik, Dîvânu Lugâti't-Türk.

\section{Onomatopoeia and The Causality Principle of Language}

\author{
ABSTRACT \\ The link between the signifier and the signified is arbitrary in linguistics. Onomatopoeia can be shown as \\ an exception to this situation. Onomatopoeia are a method that is born within the framework of certain

\footnotetext{
* Bilim Uzmanı, Ondokuz Mayıs Üniversitesi, Lisansüstü Eğitim Enstitüsü Türk Dili ve Edebiyatı Anabilim Dalı Yüksek Lisans Öğrencisi, Samsun/Türkiye. E-posta ferridik13@gmail.com, ORCID ID: 0000-0001-6891-0324

Teşekkür: Çalışmalarımda her zaman değgerli bilgileriyle bana yol gösteren Prof. Dr. Özen YAYLAGÜL ÜSTÜNEL'e sonsuz teşekkürlerimi sunarım.
} 
rules and transfers the sound of nature to the language. The debate on whether these words have a reason or no reason has been going on for a long time; While reflexive words are seen as causal by some linguists, they are seen by some linguists without reason, that is, it is reported that there is no connection between the signifier and the signified of the onomatopoeia. Onomatopoeia are seen in all world languages and language groups. Even if the onomatopoeia in languages and dialects are born for the same reason, they can differ in languages and even dialects. In Turkish dialects, this situation is seen as the dialects move away from each other. This causes us to consider the discussion of the reasoned or non- onomatopoeia once again. When we look at the real truth, even if the onomatopoeia are born from the same reason, they change by being engraved on the deep points of culture and history in the transmission of each language and dialect to its own culture, history, formation, non-linguistic effects, and most importantly, from generation to generation. The onomatopoeia in Dîvânu Lugâti't-Türk, one of the most important works of Turkish culture, have also undergone some minor changes while being transferred from generation to generation. When we compare the onomatopoeia in Dîvânu Lugâti't-Türk with the Oghuz group Turkish dialects, we can see that they have not undergone great changes. While some of the changed onomatopoeia are named completely differently, some of them have entered into harmony according to their own formations of the dialects.

Keywords: Onomatopoeia, the principle of irrationality of language, reflection, causality, Dîvânu Lugâti'tTürk.

\section{GíRiş}

Her ne kadar temeli bilinmese de dillerin doğuşunda doğadaki seslerin taklit edilmesinin önemli bir yeri olmuştur. Bu da yansıma kelimelerin tarihî bir değere sahip olduğunu göstermektedir. Dünya dillerinin ve lehçelerinin hemen hepsinde yansıma sözcükleri görmekteyiz. Günümüzde yansıma sözcüklerin önemi bir ünlem kadar, bir bağlaç kadar veya dilin herhangi bir unsuru kadar önemli görülmemekte ve göz önünde bulundurulmamaktadır. Yansıma sözcükler dilin oluşum çağından günümüze kadar sürdürülmektedir. İfade edemediğimiz fikirlerde, sözün hakiki anlamında kelimelerin yetmediği zamanlarda, korku, sevinç zamanlarında, kederlendiğimiz zamanlarda kelimeyi ifade edebilmemizde yansıma sözcükler bize ilk yardımcı olan dil mirasıdır. Kısacası yansıma sözcükler birtakım seslerin, gürültülerin insanda yarattığı duyuların adlandırılmasıyla, bunların söz biçimine getirilmesiyle olmuştur. Hamza Zülfikar'ın dediği gibi "Dilin yapısına yaklaşılarak ses yansımalarına has bir sistem içinde tabiattan elde edilen bu gürültüler, sözcüklere dönüștürülerek bu yolla canlı ve renkli anlatımlar sağlanmıștır" (Zülfikar, 1995: 1).

İnsanların, hayvanların ve tabiatta olan öteki canlı ve cansız varlıkların dolaylı ya da doğrudan ürettikleri sesler insanların işitme organına erişmekte ve bu sesler söz biçimine dönüşmektedir. Gürültülerin niteliklerine göre bunları değerlendirme özelliğine sahip olan insan, bu ses dalgalarını algılayarak dilin imkânları içinde söz biçime getirmektedir (Zülfikar, 1995). Tabiatın zenginliğini ve hareketliliğini insanlar, niteliklerine yakın bir tarzda adlandırmaya çalışmıştır. Belirli bir sesin, gürültünün dildeki yakın yansıması olan sözler, dünya dillerinin yapı karakterine uygun bir tarzda, genellikle tek heceli olarak, yalın bir şekilde ortaya çıkmıştır.

\section{Amaç}

Yansıma sözcüklerde göstergenin nedenli olup olmadığı tartışması tam ispatı bulunmayan, tam çözümü olmayan konulardan biridir. Çalışmamızın da amacı bu konu üzerinde durarak, yansıma sözcüklerin nedenli olup olmadığını belirlemek ve Dîvânu Lugâti't-Türk'teki yansıma sözcüklerin Türk dil gruplarındaki durumunu karşılaştırmalı olarak göstermektir. Aynı zamanda çalışmamızın diğer amacı ise günümüz dillerindeki ve lehçelerindeki yansıma sözcüklerin 
benzerlik durumlarının nasıl olduğunu ve bir yansıma sözcüğün dil veya lehçelerde nasıl değişikliklere uğradığını belirlemektir.

\section{Yöntem}

Çalışma kapsamındaki dil ve lehçelerle ilgili sözlükler taranarak yansıma sözcükler tespit edilmiş ve karşılaştırma yöntemi kullanılarak dil ve lehçeler arasında yansıma sözcüklerin benzerlikleri ve farklılıkları bulunmaya çalışılmıştır. Aynı zamanda Dîvânu Lugâti't-Türk'teki yansıma sözcükler de taranarak art zamanlı - karşılaștırmalı yöntem izlenmiştir. Daha sonra elde edilen veri dilin nedensizlik ilkesi açısından yorumlanmıştır. Çalışmamızda yansıma sözcükler ve dilin nedenlilik ilkesinden bahsedilmektedir. Makalede çalışma sınırlarını aştığı için bütün dil ve lehçelere girilmemiş, Azerbaycan Türkçesi, Türkmen Türkçesi, Gagauz Türkçesi, Horasan Türkçesi, Güney Kırım Türkçesi (Oğuz grubu Türk lehçeleri), Özbek Türkçesi, Kazak Türkçesi, Kırgız Türkçesi, Rusça, Ingilizce, Fransızca, Ukraynaca, İspanyolca ve Portekizce dilleri ve lehçeleri ile sınırlı kalınmıștır. Aynı zamanda Dîvânu Lugâti't-Türk teki yansıma sözcükler hakkında da bilgiler verilmiş, Oğuz grubu Türk lehçelerindeki yansıma sözcükler ile Dîvânu Lugâti't-Türk teki yansıma sözcükler karşılaştırılmıștır. Çalışmada yansıma sözcüklerin hakkında bilgiler verilip, onların nedenli olup olmadığı ile ilgili tartışmalar ele alınmıştır.

\section{BULGULAR}

Bir çağdan ötekine geçerken geçmişin şimdi üzerindeki etkisi kültürün en derinlerine kadar işler. Dil ile kültür arasında olan bu sıkı bağı açıklayan Saussure aynı zamanda göstergenin nedensizliğini de vurgular. Bu çalışmada yansıma sözcüklerin hangi derecede nedenli olduğu ve Dîvânu Lugâti't-Türk teki yansıma sözcüklerin günümüz Oğuz grubu Türk lehçelerindeki durumu ele alınmıştır. Yansıma sözcükler bazı bilim insanlarına göre nedenli bazılarına göre ise nedensizdir. Yansıma sözcükler dünya dillerinin hemen hepsinde büyük oranda farklılık göstermektedir. Aynı durum Türk lehçelerinde de birbirlerinden uzaklaştıkça daha fazla olmak üzere kendini göstermektedir. Yansıma sözcüklerin hepsi aynı nedenden doğuyorsa dil ve lehçeler arasındaki farklılığın nedeni nedir, sorusuna cevap olarak şu söylenebilir: Tarihin dile yansıması olarak baktığımız zaman her dil ve dil grubu kendi kültürüne, oluşum durumuna, konumuna, üzerinde olan etkilere bağlı olarak yansıma sözcükleri farklı işaretlemiştir. Buna bağlı olarak yansıma sözcükler, dil ve lehçeler arasındaki benzerliğinin bozulması sonucu ortaya çıkmaktadır. Bu da yansıma sözcüklerin nedenli veya nedensiz olma tartışmasını devam ettirecek gibi görünmektedir. Dilbilim alanında Saussure (Saussure, 1916) ve Hockett (Hockett, 1958) dilin nedensiz olduğunu ve dilde sözcüklerin nedensizlik ilkesi temelinde oluştuğunu söylerken Benveniste ise zıddını söylemektedir. Bemeveniste’ye göre gösteren ile gösterilen arasında ilişki nedensiz değildir (Aslan, 2007). Gösteren ile gösterilen arasındaki bağ ilișkisi dünya dillerinin hepsinde nedensiz olurken yansıma sözcükler ise bu duruma tamemen ters olarak bilinmektedir. Gösteren ile gösterilen arasındaki bağ belirli kurallarla ve nedenli olarak doğmaktadır. Bu da yansıma sözcüklerin dilin nedenlilik ilkesinin bir parçası olduğunu göstermektedir.

Yansıma sözcüklerin nedenli veya nedensiz olması tartışması bilimde cevabını tam olarak bulmamıştır. Bu sözcüklerin anlamı, olayla ilişkisi ve işlevi hakkında bir görüş ayrılığı vardır (Haciyev, 1999). Yansımalar, canlı cansız bütün varlıkların çıkardıkları sesleri yansıtan, (özellikle canlı varlıkların) dış görünüşlerini ve hareketlerini betimleyen, insanların yalnız kendilerinin deri, koku ve tat alma yoluyla hissedebildiği duyuları, sezimleri karşılayan sözcüklerdir (Koca, 
2012: 1). Buradan da bir soru doğar. Yansıma Sözcükler, nedenli midir; nedensiz midir? Soruya dünya dillerini ve Türk lehçelerini karşılaştırarak basit bir örnekle bakalım.

Anır- yansıma sözcüğü Türk lehçelerinde ve dünya dillerinde şu şekilde adlandırılıyor; Azerbaycan Türkçesinde - angır, Kazakça - alama, Özbekçe hängrä, Kırgızca - aykır, Türkmence - aňňır

Eğer anır- yansıma sözcügü tek bir nedenden doğuyorsa ve nedenliyse, Türk lehçeleri birbirlerinden uzaklaştıkça görülen farklılığın nedeni nedir? Bu da yansıma sözcüklerin nedenli veya nedensiz olma tartışmalarından birini de ortaya çıkarıyor. Başka bir örnekle bakarsak farklı dillerde farklı sonuçlar görebiliriz:

İngilizcede - bray, Fransızcada - braire Rusça - krichat, Portekizce - zurro, Ukrancada - zareviv, İspanyolcada - rebuznar

Bazı yansıma sözcükler ise yapı bakımından dil ve lehçelerde benzerlik gösterebilir. Bu örnekler ise yansıma sözcüklerin nedenli veya nedensiz olması tartışmasını daha çok ortaya koymaktadır. Sebebi ise gösterdiğimiz örneklerde dil ve lehçelerin benzerliğinin daha fazla olmasıdır. Burada daha farklı soru ortaya çıkmaktadır. Dil ve lehçeler arasında farklılık olsa dahi benzerliğinin nedeni yansıma sözcüklerin nedenli olması mıdır? Örneklersek:

Miyavla- yansıma sözcüğü Türk lehçelerinde ve dünya dillerinde şu şekilde adlandırllıyor; Azerbaycan Türkçesinde - miyav, Kazakça - miyau, Özbekçe - myau, Kırgızca - miyau, Türkmence - mav

İngilizcede - mew, Fransızcada - miauler, Rusçada - myau, Portekizcede - miado, Ukrancada - nyav, İspanyolca - maullar

Yukarıda söylediğimizin aynısını diller için de söyleyebiliriz. Saussure nedensizliği șu șekilde açıklıyor: Dilsel göstergenin nedensizliği ve dolayısıyla rasyonelliğe dayalı olmayışı, tartışmaya kapalılı̆̆ı da beraberinde getirir. Çünkü bir şeyin tartışılabilmesi için akla uygun bir kurala dayanması gerekir. "Fr. soeur "kızkardeş”i İng. sister’e, Alm. ochs’u Fr. boeuf “öküz"e yeğlemek için hiçbir neden yoktur" (Saussure, 1998: 119). Saussure elbette istisnai durumların olduğunu kabul etmektedir. Sesin dille yansıma durumları vardır, ancak örnekleri kısıtlıdır, buna kısıtlılık denebilir ki genel durumu sarsacak nitelikte bir kurallılık durumunu yansıtmamaktadır. Dil göstergelerinin nedenli olabildiği, daha açık söylersek, onları daha az nedensiz kılabildiğimiz iki yol var. İlkin, göstergenin sesinin herhangi bir biçimde mimetik ya da yansılamalı göründüğü yansıma (onomatopoeia) durumları vardır Söz konusu durum haricinde Saussure, benzer şekilde ünlemler için de onların doğal olarak açığa çıktıklarının sanıldığını fakat aksine ünlemler söz konusu olduğunda da yine gösteren ile gösterilen arasında zorunlu bir ilişkinin bulunmadığını ileri sürer (Saussure, 1998: 119). Göstereni gösterilenle birleștiren bağ nedensizdir. Göstergeyi, bir gösterenin bir gösterilenle birleşmesinden doğan bütün olarak gördüğümüzden daha yalın olarak şöyle de diyebiliriz; dil göstergesi nedensizdir. Örneğin, "kitap" kavramının kendisine gösterenlik yapan $k$-i-t- $a$ - $p$ ses dizilişiyle hiçbir iç bağıntısı yoktur. Başka herhangi bir diziliş de onu aynı oranda gösterebilir (Köktürk, Eyri, 2013).

“Hakkı Devrim'in “Sen, mesela nobranlardan hoşlanmazsın." gibi bir tümcesiyle karşılaştınız ve üçüncü sözcügü bilmediğinizi düşünelim. Anlamını bulmak için sözlügünüzde nasıl bir tarama yapardınız? Sözcüğü olduğu gibi koruyup nobranlardan diye mi, yoksa nobran diye mi, arardınız? 
Uluslararası Türk Dünyası Bilimsel Araștırmalar Dergisi International Journal of Turkish World Scientific Researches

Birinci yolu seçerseniz, bu sözcüğün hiçbir sözlükte listelenmediğini göreceksiniz. Bunun yerine, bütün sözlüklerde çekirdek yapıya indirgenmiş biçimi olan nobran sözcügünü bulacaksınız. Yer ve gereksiz yineleme sorunu yaratmamak için, kural işletilerek çözümlenebilecek bilgilerin sözlüklerde listelenme geleneği yoktur. Nobran sözcüğünün başkaca nobranlar ve nobranlardan gibi biçimlerinin olabileceği, gerçek dilde kullanılan çocuk, çocuklar, çocuklardan gibi benzerlerinden yola çıkarak kestirilebilir bir bilgidir. Oysa nobranın kendisinin anlamını bulmak için böyle bir çıarsama olası değldir; çünkü dilde sözcükler nedensizlik ilkesi (Saussure, 1916: 67; Hockett, 1958: 577) temelinde oluşurlar. Bir sözcügü oluşturan sesler çoğu zaman ifade ettikleri anlamdan bağımsızdır" (Balcı, 2011: 23).

Dilsel göstergenin nedensizliği düşüncesi beraberinde birtakım itirazlar getirmiş ve çeșitli tartışmalara yol açmıştır. Benveniste, Saussure'ün gösteren ile gösterilen arasında nedensizlik bulunduğunu ileri sürmesini eleștirerek, nedensiz olanın gösterge ile nesne arasındaki ilişki olduğunu ifade eder:

Benveniste GDD'ye bağlı olarak Saussure'ün gösteren ile gösterilen arasında nedensizlik bulunduğu görüşünü şu şekilde eleștirir: $k$-a-r-d-e-ş ses dizisi "kardeș" kavramından bağımsız yalnızca bir ses yığınıdır, öyleyse gösteren ile gösterilen arasında ilişsi nedensiz değil zorunludur; nedensiz olan gösterge ile nesne arasındaki iliş̧idir, çünkü dildeki sesler hiçbir biçimde dış dünyadaki nesnelere karşılık gelmez (Benveniste'den alıntılayan Aslan, 2020: 7).

Benveniste devamında Saussure'ün "kardeş" kavramının $k$-a-r- $d-e$-ş gösterenine bağlanmadığını söylemesinin boșuna olduğunu ekler, aslında yine de Saussure ona göre kavramın gerçekliğini düşünmektedir. Benveniste benzer şekilde dilsel göstergenin nedensizliğine ilişkin yaklaşımın zihin ve dış dünya arasındaki metafizik probleme ilişkin konuşan kişinin bu soruya içgüdüsel olarak getirdiği çözüme yönelik dilbilimcinin bir savunması olduğunu düşünmektedir (Öztokat, 1995: 75-77).

"Sözcükler ile bu sözcüklerin göndergeleri arasındaki bağ hiçbir koşulda doğal değildir, hatta yansıma sözcüklerin dahi farklı dillerde farklı biçimlerde ifade edilmeleri bu bağın doğal olmadığının kanıtıdır. Bu nedenle dil nedensizdir, nedensiz olan dil ise, buyrultusaldır; dolayısıyla uzlaşımsaldır. İște dili toplumsal kılan da budur. Bununla birlikte toplumsal olarak ortaya konan her ürün, toplumsal göstergebilim yoluyla anlamlanmaya muhtaç göstergelerle doludur. Bütün bunlar bir arada değerlendirildiğinde, uzlaşımsal olması ve göstergelerden oluşması nedeniyle, literatürde çeşitli yönleriyle ele alınan "dil"in toplumsal göstergebilimsel bakış açısıyla ele alınması gereken bir alan olduğu açıcça görülmektedir" (Erol, 2014: 213).

Guiraud "Anlambilim" çalışmasında göstergenin nedenli olup olmadığı hakkında görüşlerini şu şekilde paylaşmaktadır (Guiraud, 1999: 35-38): “Gösterenle gösterilen arasında, konuşanların anlaşmasından doğan bir bağıntı dışında bağıntı bulunmadığı ölçüde gösterge nedensizdir. Varsa, göstergenin nedenli olduğu söylenir. Göstergenin nedensizliği sorunu Saussure'den bu yana birçok tartışmaya yol açmıștır. Anlaşllıyor ki Saussure özellikle, kendi çağında geçerli olan ve seslerin yansımalı kökeni bulunduğunu savunan kuramı hedef alıyor; ama başka düzlemlerde nedenlilik kavramını bir kenara itmiyordu. Burada üç kavram karşımıza çıkıyor: Nedensizlik, nedenlilik, saymacalık (anlaşma). Nedensiz, nedenliyle karşıtlaşır ve saymaca ya varır: Çünkü hiçbir nedenlilik bulunmadığında anlamlamayı tek başına saymacalık sağlar. Ne var ki saymaca, nedenliyi ortadan kaldırmaz. Dil göstergesinin özü saymacalıktır, nedensizlik değildir. Saymacalık göstergeyi nedensizleştirmeye yönelir, ama nedenlilikle de çelişmez. Yalnız, nedenlilik bu 
durumda ikincil bir özelliktir, dolaysız bir zorunluk taşımaz, onun için de bozulma, bulanıklaşma, çoğu kez de silinme eğilimindedir". Guiraud nedenlilik ve nedensizlik hakkında iki önemli görüş paylaşmaktadır: 1. Kullandığımız sözcüklerin büyük bir bölümü gerçekten de nedenlidir; duruma göre değişik oranlarda bilinçli olan bu nedenlilik, anılan sözcüklerin kullanım ve evrimini belirler. 2. Her yeni sözcük zorunlu olarak nedenlidir; her sözcük başlangıçta nedenlidir ve duruma göre kısa ya da uzun bir süre böyle kalır; sonra nedenlilik anlaşılmaz olur, sözcük nedensizleșir (Guiraud, 1999: 36).

Belirli kurallar çerçevesinde doğan yansıma sözcükler doğanın ve doğada olan canlıların sesini, görüntüsünü ve şeklini duyularımız vasıtasıyla sözcüğe aktarmamıza yardımcı olan dil unsurudur. Bu da yansıma sözcüklerin nasıl doğduğunu ve nedenli olarak kullanıldığını göstermektedir. Ses biçiminde gösterge ile gösterilen arasındaki benzerliğe dayanan yansıma sözcüklerde dolaysız ve doğal ses nedenliliği vardır. "Demek ki her sözcüksel yaratım her zaman nedenlidir. Yaratım saymacalık dışı çağrışımlara dayanır. Gösterenle gösterilen arasındaki çağrışım (yansımalar) biçimbilimsel nitelikli olan ya da yakınadlılığa dayanan iç çağrışımlardır" (Guiraud, 1999: 49). Yansıma sözcükler dilin nedenlilik ilkesinin bir parçası olmaktadır.

Kıran (1996: 64), yansıma sözcükleri şu şekilde açıklamaktadır: "Dilde "nedensizlik ilkesi" bilindiği gibi gösteren ile gösterilen arasındaki zorunlu ilişkiden kaynaklanan nesne, düşünce ile göstergenin kendisi arasındadır. Öte yandan dilsel işletimde türetmeler, bileşik biçimler, önekler ve soneklerle kurulan bütün yapılar ikinci dereceden nedenlilik gösteren göstergelerdir. Örneğin, $\mathrm{kapl} / \mathrm{cl}>\mathrm{kapıcl}$ gibi iki ayrı birim nedensizlik ilkesiyle dilde yer alırken kapıcı türetimi ikinci dereceden nedenlilik gösterir. Saussure ise aynı işletimi "salt nedensizlik" ve "görece nedensizlik" olarak adlandırır. Öte yandan, yansıma sözcükler biçimleri birinci dereceden bir nedenlilik örneğidir. Dilbilimde, kelimenin belirttiği kavram ile kelimeyi oluşturan ses birimleri arasında bir nedensellik bağı olmadığını belirten görüşe "Göstergenin Nedensizliği İlkesi" denilmektedir". Nedensizlik durumu ile "yansımalar" (Onomatopeia) yani "doğa sesleri" durumu birbirlerine neredeyse zittır.

\section{Yansıma Sözcükler (Onomatopeia)}

Bir dilde yansıma kelimelerin tespiti çok kolay değildir, bu nedenle yansıma kavramının ne demek olduğu iyi anlaşılmalıdır. Yansıma kelimeler, hareketlerin betimlenmesi ve duyulan seslerin taklit edilmesi sonucunda dil özelliklerine göre görünüşlerin ve seslerin şekil alması olarak ifade edilebilir. Banguoğlu, yansılama terimini kullanarak "tabiat seslerini tasvir veya kabataslak taklit ederek meydana gelmiş ses toplulukları" șeklinde tanımlar (1974: 402). Banguoğlu'na göre; “Bu basit ve uzatılmış kök kelimeler taban olmak üzere yansımalar üretim ve birleşim yollarıyla kelime doğarcığımıza geniş ölçüde ve pek renkli kelimeler sağlamışlardır. Yansılama kökleri isim tabanları teşkil ettiklerine göre onlardan isme ek isim ve isme ek fiil ekleriyle yapılmış isimler ve fiiler olmalıdır. Gerçi öbür isim kökleri gibi yansımalara da herhangi bir yapım eki gelmesi mümkündür. Nitekim onlar her türlü birleşik kelime yapımına da girerler" (Banguoğlu, 1959).

Bazı yansımaları da tespit etmek çok kolaydır. Örneğin, "tak tak, çıtırtı, tıkırtı, güm” gibi sözcüklere bakıldığında kelimelerin yansıma kavramında olduğu rahat fark edilebilir. Fakat dildeki morfolojik özellikleri üzerine alarak isim ya da fiil şeklinde kullanılan yansıma kelimeleri tespit etmek biraz zordur. Bu durumda dilin fonetik ve morfolojik özelliklerinin hakkında iyi bilgiye sahip olunması gerekir. Kelimelerin tespiti konusunda dikkatli olunmalı ve ekler ayrılarak yansıma köklere ulaşılmalıdır. Ancak bazen ulaşılan her kök Balkaya'nın belirttiği gibi yansıma sözcüklerle aynı sesleri taşıyor olsa bile yansıma olarak kabul edilemez. Örneğin ıslık yansıma 
Uluslararası Türk Dünyası Bilimsel Araștırmalar Dergisi International Journal of Turkish World Scientific Researches

kökenli bir isimdir. Islık kelimesi yansıma kökenli olduğu için "1s" köküyle türetilen bütün sözcükleri yansıma olarak değerlendiremeyiz; ıslanmak, ısınmak, ısı, ıslak gibi kelimeler, içinde aynı sesi barındırmasına rağmen farklı köklerden oluşan sözcüklerdir (Balkaya, 1996: 24).

Yansıma kelimeler zaman geçtikçe gelişmekte olan dil unsurlarından biridir. Her zaman farklı kullanılabilir ve her zaman yeni tür kelime ile söylenebilir. Bu da insanların tepkisine göre daima

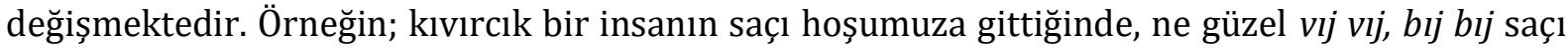
var diyebilir veya kıvırclk kelimesinin kendisini de kullanabiliriz. Buradan da yansıma kelimelerin farklı kelimelerle aynı fikri ifade ettiğini görebiliriz. Yansıma kelimeler, her dilde, özellikle Türkçenin konuşma dilinde edebi eserlerde, masallarda, atasözünde ve şiirlerinde yaygın kullanılan ve bir ifadeyi, kavramı daha kalıcı, duygusal, canlı bir şekilde veren kelimelerdir (Omuralieva, 2021).

Yansıma sözcükleri oluşturan ses birimlerin seçilmesi ve dizilişi arasında dildeki diğer sözcüklere nispeten daha sıkı bir ilișki vardır. "Bu sözcüklerde dil dıșı göndergelerin ses, yapı veya hareketlerinin karakteristik özelliklerine göre sesbirimler çeşitlenir". Buna göre kök biçimleri ve eklerindeki sesbirimlerin anlam ayrıștırıcı özellikleri bulunmaktadır (Karahan, 2008: 140-148).

Osmanlı döneminde yansıma kelimeler (taklidi kelimeler veya onomatopeiler) "lafzı taklidi", "savtı taklidi" son olaraksa "taklidi kelimeler" biçiminde kullanılmaya başlanmıştır. "Taklidi kelimeler" terimi önce Latinceye oradan da Batı dillerine geçmiştir. "Onomatopei"; Grekçe "onoma" ve "poein" kelimelerinden oluşan bir birleşik kelime olup "onoma" kelime veya ad, "poein" ise ad kurma veya ad verme diye çevriliyor. İngilizcede bu alana "imitative words", "echo words" ve "sound symbolism" terimleri verilmektedir. Söylediğimiz bu adlandırmalar Batı dillerinde küçük ses değişimleri ile geçmektedir. Alman dilinde ise "lautbild" ve "lautmalerei" terimleri kullanılmaktadır. Rusçada ise yansımaların karşılığı "podrajatelnie", “zvukopodrajatelnie” vü "mimologie” terimleridir (Zülfikar, 1995).

Türkiye'de yapılan çalışmalarda yansıma kelime kavramına derinden dokunulmamaktadır. Konu üzerinde ilk derli toplu çalışma 1995 yılında Hamza Zülfikar tarafından yapılmıştır. Zülfikar Türk dilinde çok araştırılmamış konulardan birinin de ses taklidi (ses yansımalı) kelimeler olduğunu belirtmektedir. Türkçenin söz varlığı içinde, özellikle de ağızlarında önemli bir yer tuttuğunu ve bu tür kelimelerin yapıları, işleyişleri, kavramları bakımından ayrı bir kelime grubu oluşturduğunu söylemektedir. Düzenli ve kurallı bir şekilde söylenen yansıma kelimeler, anlatıma canlılık katar. Konuşma dilinde canlı kalmış yansıma kelimeler, yıllar boyunca kullanılmış ve günümüze kadar gelmiş, dönemler arasında kolayca aktarılmıştır. Öte yandan günümüze kadar gelen bu kelimeler daha da zenginleşmiş, çeşitlenmiş ve gerektiğinde yeni adlandırmalar da yapılmıştır (Zülfikar, 1995: VII).

Yansıma kelimeler, dilin oluşumunda rol oynamıştır. Bununla birlikte, bu rol çok sınırlı ve genel dil oluşumu sürecinde anahtar faktör olarak çok az öneme sahipti. Bu kelimeler, dilin kökenini bir bütün olarak açıklamada yararlı olmasa da tek tek kelimelerin etimolojisini belirlemek için onları incelemek gerekmektedir. Yansıma kelimeler yalnızca duyulabilecek şeyleri ve olayları tanımlayabilmektedir. Elbette bu olay, duyulabilecek her şeyin ve olayların isimlerinin metafor olması gerektiği anlamına gelmez (Rüstemov, 1998). Balkaya (Balkaya, 1996: 9), durumu şu şekilde açıklar; "Gerçekte hiçbir sözcügün dış gerçeğin çıkardığı bir sesi tamamen öykündügü ileri sürülemez. Ancak bir nesnenin ya da canlının çıkardığı sesin bir uzlaşma sonucu ülküsel bir biçim kazanarak uyandırdığı işitimsel izlenimle dilin sözcükler ile, kendi yaptığımız yansıma sözcükler arasında yakınlık kurularak bir sözcüğün yansılama olduğu kabul edilebilir. Bu konuda farklı 
dillerde aynı sesin farklı biçimlerde yansılandığı bir kanıt olarak öne sürülebildiği gibi hatta aynı dilde aynı sesin farklı dönemlerde ya da bölgelerde farklı yansıtılmaya çalışıldığı da saptanabilir" (Demir, 2019: 16).

\title{
Dîvânu Lugâti't-Türk’te Yansıma Sözcükler
}

Türkçenin büyüklügüne zenginlik katan, Türk dünyasına armağan kalan eserlerden biri de Dîvânu Lugâti't-Türk'tür (DLT). Bu büyük değere sahip eser içinde bulundurduğu pek çok temel kelime ile Türkçenin özünü göstererek birçok kelimenin kaynağını oluşturmaktadır. Büyük ve yüklü bir sözlük olan DLT yansımaların tarihini de nerdeyse kendinde göstermektedir. Bugün birçok yansımalar o devrin temelinde oluşmuştur ve aynı yansıma sözcüklerin bugün de kullanıldığını görmekteyiz. Bazı küçük ses farklılıkları olsa bile aynı anlam değerlerine sahiptirler. Kazın kağ kuğ diye ses çıkarması, atın kişnemesi, hayvanların korkudan ürkmesi, köpeğin ürmesi, sert eşyanın pat diye düşmesi, koyunların meleşmesi vb. benzeri yansımalar gibi.

DLT'de yansıma seslerden üretilmiş fiiller de vardır. Örneğin: Bir kedinin miyavlaması, kedinin çıkardığı sesi sözcüğe dönüştürerek miyav ismiyle $+l A$ - isimden fiil yapan ekin gelmesiyle yansıma sözcük oluşturulmuştur. Bu kelimeye tarihi açıdan baktığımız zaman da dilin oluşumunda miyav sözcügü aynı şekilde yansımıştır, DLT döneminde de aynı şekilde yansımış ve günümüz Türkçesinde de aynı şekilde dile yansıyarak kelime olmuştur.

İnsan ruhunun ve duyularının sonucu ortaya çıkan yansımalar DLT'deki kelimelerde belirli şekilde ve net olarak kendini göstermektedir. Yansıma kelimeler, kimi zaman doğrudan sesi kimi zaman da o sese ilişkin algıyı ya da izlenimi karşılar. Bu nedenle yansımalarda, gerçek bir sesin belli oranda saymacalık içeren ses öykünmesi yoluyla belirtilmesi söz konusudur. Yansıma kelimeler zengin içeriğe sahip olup Türkçenin önemli bir parçası olmaktadır. Aynı zamanda DLT de büyük lügat içeriğine sahip olmakla beraber yansıma kelimelerin de bir kısmını kendinde bulundurmaktadır. Bu kelimeler bize tarihten gelen Türkçenin geçmişte nasıl kullanıldığını, ne durumda olduğunu ve kullandığımız kelimelerin geçmişi, yapısı hakkında bilgi vermektedir. DLT'deki bu yansıma sözcükler günümüze kadar geldiği dönemde, bazı yansıma sözcükler fonetik değişikliklere uğrarken, bazıları olduğu gibi kalmakta, bazıları ise tamamen değişmektedir. Bu durumu küçük örneklerle gösterirsek:

\section{Fonetik Değişiklik Gösteren Yansıma sözcükler}

\author{
Arslan kökredi - aslan kükredi (DLT, 3: 282) \\ Böri barça ulışdı - bütün kurtlar uluştu (DLT, 1: 188) \\ Er asurdl - adam aksırdı (DLT, 1: 178) \\ Er kegirdi - adam geğirdi (DLT, 2: 84) \\ Oglan ıgladı - çocuk ağladı (DLT, 1: 287) \\ Suw tamdl - su damladı (DLT, 2: 26)
}

Taş kuduğda külredi - taş kuyuda gürledi (DLT, 3: 283) 
Yek anğıladı - eşek anırdı (DLT, 1: 311)

Zap Zap bargıl - zıp zıp koşmak (DLT, 1: 319)

\section{Değişmeyen Yansıma Sözcükler}

Er ahladı - adamcağız, ah dedi, ah diye ses çıkardı (DLT, 3: 118)

It ürdi - it ürdü (DLT, 1: 164)

Koy ürkti - koyun ürktü (DLT, 3: 420)

Oglan çişedi - çocuk çişedi, çiş etti (DLT, 3: 267)

Ol konğragu çınğradı - o çan çınladı (DLT, 3: 402)

Ol koyun kırkdı - o koyunun yününü kırktı (DLT, 3: 422)

Ol meni öpdi - o beni öptü (DLT, 1: 163)

Titir bozladı - diși deve bozladı, bağırdı (DLT, 3: 291)

\section{Tamamen Değișen Yansıma Sözcükler}

At bırkırdı - at homurdandı, genizden ses çıkardı. (DLT, 2: 171)

At okradl - at kişnedi (DLT, 1: 275)

Berge çatıladı - kamçı şakladı (DLT, 3: 323)

Er öfkesinde ürüldi - adam öfkesinden şişti, kabardı (DLT, 1: 195)

Er suw opdl - adam suyu höpürdeterek yudumladı (DLT, 1: 172)

Kagun buk yerge tüştü - kavun pat diye ses çıkararak yere düştü (DLT, 3: 129)

Kapuğ çıkradı - kapı gıcırdadı (DLT, 3: 280)

Kuş sıkırdı - kuş ıslık gibi ses çıkardı (DLT, 2: 83)

Ol kişi yüzinğe suttı - o, adamın yüzüne tükürdü (DLT, 2: 295)

Sanduvaç sayradı - bülbül şakıdı (DLT, 3: 311)

Tars kars aya yaptı - o, el ayasını birbirine vurarak ses çıkardı (DLT, 1: 348)

Örneklere bakarsak yansıma sözcüklerin çoğunun eski şeklini korumakta olduğunu ve büyük değişikliklere uğramadığını görebiliriz. Değişikliklerin XI. asırdan günümüze kadar Türkçenin gelişimi dönemlerinde dış etki gibi faktörlerden ve ağız farklılıklarından kaynaklandı̆̆ını belirtebiliriz. Karşılaştırdığımız örneklere Türkiye Türkçesinin de üyesi olduğu Oğuz grubu Türk 
lehçelerinde de bakarsak aynı değiş̧iklikler farklı şekilde göze çarpacaktır. Yansımalar zaman geçtikçe lehçelerin birbirlerinden ayrılması sonucu kelime anlamında ve işlevinde küçük değişiklikleri de kendisiyle getirmiştir:

Div yuxudan bidar olub, qıza bir şapalaq çəkdi ki, niyə qoyursan məni milçək yeyə. (Örnek "Məlik Məmməd və Məlik Әhməd" masalından alınmıștır.)

Azerbaycan Türkçesinde ve Türkiye Türkçesinde kullanılan "şapalaq" kelimesi yansıma yoluyla türemiş kelimedir. Bu kelimeyi Türkiye Türkçesine olduğu gibi aktarmak doğru olmaz, şapalaq kelimesinin yerine yansıma kelime olan "tokat" kelimesini kullanmak en doğru aktarım olur.

Dev uykudan kalkıp kıza bir tokat vurmuş. Demiş ki; neden beni sivrisineğin ısırmasına izin veriyorsun?

Başka bir örnekle bakarsak DLT"de “çır” (DLT, 1: 323) olan yansıma kökenli kelime Oğuz grubu Türk lehçelerinin hepsinde "cırt" (elbise ve benzeri şeylerin yırtılma sesi) olurken Güney Kırım Türkçesinde "Cır" olarak korunmuştur. "Çınğ" (DLT, 1: 367) yansıma kelimesi de aynı şekilde bütün Oğuz grubu lehçelerinde "çın" olarak kullanılırken Türkmen Türkçesinde "şan̆" olarak kullanılmaktadır.

Bazı yansıma kelimeler ise DLT'den beri hiç değişmemiştir: “Ahla" (DLT, 3: 118) kelimesi DLT'de de "ahla", Oğuz gurubu Türk lehçelerinde de "ahla" olarak görülür. Öp, tın, ses, ürk, buk, çağla, pat vb. birçok örnekler bulunmaktadır.

Bazı yansıma kelimeler ise fonetik veya morfolojik olarak farklı olurken anlam ve işlev bakımından aynı olmaktadırlar: Çocuk durmadan aksırdı (AzT. Asqırdı, TrkmT. Asgırdl, GaT. Ansırdı, GKrmT. Siskirdi, HorT. Asqırdı). Buna benzer olarak birçok örnekler de bulunmaktadır (ık, hünkür, abur cubur, çişe, çın, şaşmak, ürpek, buk, kırk vb.).

Yansıma sözcükler yalnız Türkçede veya Türk dünyasında değil, bütün dünya dillerinde kullanılan dil unsurlarıdır. Biz nasıl bir cismi, bir düşünceyi veya bir olayı izahsız şeklide anlatmaya çalışırken kelimelerin yetmediği anda yansıma sözcüklere başvuruyorsak bütün dünya dillerinde de bu olay aynı şekilde gerçekleşmektedir. Aksan bu fikri şu şekilde açılamaktadır. "Hangi dili ele alırsak alalım, doğadaki sesleri yansıtmaya, taklit etmeye yönelen öğelere rastlarız. Bu öğeler insan ve ses bağırmalarıyla kükreme, havlama gibi hayvan seslerini yansıttıkları gibi, ses çıkaran her türlü varlığın seslerini vermeye de yönelirler. Türkçemizdeki miyavlamak, havlamak, bögürmek, kükremek, gıdaklamak, melemek gibi hayvan seslerini gösteren eylemlere eğilirsek bunların temelde belli seslerin taklidine dayandığı, sonradan dilin belli kalıplarına dökülerek eylemleştiğini görürüz" (Aksan, 2009: 96).

Basit bir şekilde Türkçede olan yansıma sözcükleri alıp dünya dilleri ile karşılaştırdığımız zaman, ilk göze çarpan olay diğer dillerdeki yansıma sözcüklerin o dilin kendi yapısına, kendi kültürüne ve kendi tarihine dayandığıdır:

\section{Türkiye Türkçesinde - miyavlamak (DLT, 3: 14)}

İngilizcede - mew

Fransizcada-miauler

Rusçada - myau 
Portekizcede - miado

Ukrancada - nyav

İspanyolca - maullar

Türkiye Türkçesinde - havlamak (DLT, 3: 404)

İngilizcede - bark

Fransızcada - aboyer

Rusçada - lay

Portekizce - latido

Ukranca - kora

İspanyolca - lardar

Türkiye Türkçesinde - anırmak (DLT, 1: 311)

İngilizcede - bray

Fransizcada - braire

Rusça - krichat

Portekizce - zurro

Ukrancada - zareviv

İspanyolcada - rebuznar

\section{Türkiye Türkçesinde - öpmek (DLT, 1: 163)}

İngilizcede - kiss

Fransizcada - embrasser

Rusça - çelovat

Portekizce - zurro

Ukrancada - potsilunik

İspanyolcada - beso

Gösterdiğimiz örneklerden de anlaşılacağı üzere yansıma kelimeler, her dilin kendi kültürüne ve oluşumuna göre değişiklik göstermektedir. Aynı örnekleri Türk Lehçelerinde karşılaştırırsak, yansıma sözcüklerin benzerliğinin ne kadar olduğunu göreceğiz:

\section{Türkiye Türkçesinde - ağlamak (DLT, 1: 287)}

Azerbaycan Türkçesinde - ăgla-

Türkmen Türkçesinde - ağla-

Gagauz Türkçesinde - ağla-

Güney Kırım Türkçesinde - ağla-

Horasan Türkçesine - ağla-

Türkiye Türkçesinde - anırmak (DLT, 1: 311)

Azerbaycan Türkçesinde - angır-

Türkmen Türkçesinde - aññr-

Gagauz Türkçesinde - anır-

Güney Kırım Türkçesinde - anır- 
Horasan Türkçesine - angır-

Türkiye Türkçesinde - tükürmek (DLT, 2: 183)

Azerbaycan Türkçesinde - tüpür-
Türkmen Türkçesinde - tüykür-
Gagauz Türkçesinde - tükür-
Güney Kırım Türkçesinde - tükür-
Horasan Türkçesine - tüpür-

Türkiye Türkçesinde - çağlamak (DLT, 3: 324)

Azerbaycan Türkçesinde - çağla-

Türkmen Türkçesinde - çağla-

Gagauz Türkçesinde - çaala-

Güney Kırım Türkçesinde - çağla-

Horasan Türkçesine - çağla-

Yansıma sözcükler dile rengarenglik katan, her zaman değişkenlik gösteren, dil bilimciler tarafından çok da araştırılmamış ve araştırılması önemli olan konulardan biridir. Çünkü yansıma sözcükler Türk kültürün, dilin ve tarihin bir parçasıdır.

\section{TARTIŞMA VE SONUÇ}

Dilde gösterge ile gösteren arasında bağ nedensizdir. Bazı durumlarda ise bu bağ nedenli olabiliyor. Görüntüsel göstergeler olan yansıma sözcükler buna örnektir. Yansıma sözcükler de dilin nedenlilik ilkesinin bir parçasıdır. Gösterge ile gösteren arasında her zaman bir bağ vardır. Bir köpeğin havlaması, insanın korkarak bağırması, eşyanın pat diye yere düşmesi, yumurtadan yeni çıkan civcivin sesine ugun olarak adlandırılması gibi. Belirli kurallar çerçevesinde doğan yansıma sözcükler doğanın ve doğada olan canlıların sesini, görüntüsünü duyularımız vasıtasıyla sözcüğe aktarmamıza yardımcı olan dil unsurudur. Yansıma sözcüklerin nedenli olup olmaması tartışması ise her zaman dilbilim tartışmalarını kendi bünyesinde barındırmaktadır. Ses biçiminde gösterge ile gösterilen arasındaki benzerliğe dayanan yansıma sözcüklerde dolaysız ve doğal ses nedenliliği vardır. Yansıma sözcükler dilde yeni sözcükler yaratmak olanaklarından biri olmakta ve nedenli olarak doğa seslerinden doğmaktadır. Biz de çalışmamızda yansıma sözcükler ile ilgili farklı dillerden ve lehçelerden örnekler vererek yansıma sözcüklerin nedenli olup olmaması konusunda tartışmalar yürüttük. Söz konusu olan bu kelimeler faklı dillerde ve lehçelerde aynı nedenlerden oluşsa da farklı şekilde adlandırılmaktadır. Diller arasında hemen hemen yansıma sözcüklerde benzerlik olmazken Türk lehçeleri arasında bu durumun akrabalık göstergesinden dolayı benzerlik gösterdiğini ve lehçelerin birbirlerinden uzaklaşmasıyla bu benzerliğin azaldığını belirledik. Örneklerden de belli olduğu üzere, yansıma sözcükler aynı nedenlerden doğduğu halde farklı adlandırmalara tabi tutulmuştur. Bu da yansıma sözcüklerin nedenli veya nedensiz olma tartışmasını bir kısım daha üst düzeye taşımaktadır. Yansıma sözcüklerin farklı adlandırılmasının nedeni ise her dil ve dil grubunun kendi kültürüne, oluşum durumuna, konumuna, üzerinde olan etkilere bağlı olarak bu kavramın farklı gelişmesidir. Dil ve lehçeler çağ atladığı zaman yansıma sözcükler de diğer kelimeler gibi değişime uğramaktadır. Dîvânu Lugâti't-Türk ü yansıma sözcükler bakımından incelediğimiz zaman, burada bulunan yansıma sözcüklerin Türk lehçelerinde nasıl bir değiş̧ime uğradığını açıkça görebiliriz. Dîvânu 
Uluslararası Türk Dünyası Bilimsel Araștırmalar Dergisi International Journal of Turkish World Scientific Researches

Lugâti't-Türk'teki yansıma sözcükleri Oğuz gurubu Türk lehçeleri ile karşılaştırdığımızda XI. asırda yazılmasına rağmen, günümüze kadar aktarılması ve hâlâ kullanımını görebiliriz. Küçük bir kısmının da değişimlere uğrayarak tamamen başka adladırıldığını veya söz konusu lehçelerin

değişimine göre uyuma girdiğini söyleyebiliriz.

\section{KAYNAKÇA}

Akdoğan, Y. (1999). Azerbaycan Türkçesinden Türkiye Türkçesine. İstanbul: Beşir Yayınevi.

Aksan, D. (1983). Sözcük Türleri. Ankara: TDK Yayınları.

Aksan, D. (2009). Anlambilim. Ankara: Ergin Yayınevi.

Akyıldı, A. D. (2014). "Ses Sembolizmi ve Ses-Anlam Uyumunun Farklı Bir Sinıflandırma Denemesi". Türk Dili ve Edebiyat Dergisi. Cilt 57. Sayı 57.

Aslan, E. (2020). "De Saussure'de Dilsel Göstergenin Nedensizliği ve Sistem Fikri”. 29 Mayıs Üniversitesi Dergisi. Cilt 7. Sayı 1.

Atalay, B. (1985). Dîvânu Lugâti't-Türk Tercümesi I. Ankara: Türk Tarih Kurumu Basımevi.

Atalay, B. (1985). Dîvânu Lugâti't-Türk Tercümesi II. Ankara: Türk Tarih Kurumu Basımevi

Atalay, B. (1985). Dîvânu Lugâti't-Türk Tercümesi III. Ankara: Türk Tarih Kurumu Basımevi.Balkaya, D. (1996). Yansilama ve Almanca-Türkçe Ses Yansımalı Sözcükler. Basılmamış Yüksek Lisans Tezi. Erzurum: Atatürk Üniversitesi.

Banguoğlu, T. (1974). Türk Grameri (Ses Bilgisi). Ankara: TDK Yayınları.

Demir, Y. (2019). Kumuk Türkçesinde Yansıma Kelimeler. Yüksek Lisans Tezi. Nevşehir: Hacı Bektaş Üniversitesi.

Ercilasun, A. B. (2016). Türk Dili Tarihi. Ankara: Akçağ Yayınları.

Ergin, M. (1958). Türk Dil Bilgisi. İstanbul: İ. Ünv. Ed. Fak. Yayını.

Erol, P. Ö. "Bir Toplumsal Göstergebilim Alanı Olarak Dil", Uluslararası Sosyal Araştırma Dergisi. Cilt 7. Sayı 31.

Eyri, S. Köktürk, Ş. (2013). "Dilbilim ve Göstergebilim: Ferdinand De Saussure ve Göstergebilimi Anlamak". SAÜ Fen Edebiyat Dergisi II.

Ferdinand De S. (1998). Cours de Linguistique Generale. Çeviren: Prof. Dr. Berke Vardar. İstanbul: Multilingual Yayınları.

Guiraud, P. (1999). Anlambilim. Çeviren: Prof. Dr. Berke Vardar. İstanbul: Multilingual Yayınları.

Haciyev, K. (1999). Azerbaycan Dilinde Xüsusi Nitq Hisseleri. Bakı: Çaşığlu Yayınları.

Karahan, A. (2008). “Memluk Kıpçak Sözvarlığı: Yansıma Fiiller Üzerine İnceleme”. Sayı 20.

Kıran, Z. (1996). Dilbilim Akimları. (2. Baskı). Ankara: Onur Yayınları.

Kırlı, S. Uğurlu, A. S. (2016). "Her Yıl Bir Büyük Türk Bilgi Şölenleri: 3". Bursa: Uluslararası Muhammed Hüseyin Şehriyar Bilgi Şöleni.

Koca, E. (2012). “Dede Korkut Hikayelerindeki Yansıma Sözlerin Leksiko Semantik Analizi”. Cilt XII. Sayı 1. 
Omuraliyeva, A. (2020). "Türkiye Türkçesinde Ses Yansımalı Fiillerin Yapısı”. Uşak Üniversitesi Sosyal Bilimler Dergisi. Cilt 13. Sayı 12.

Omuraliyeva, A. (2021). Türk Yazı Dilleri ve Lehçelerinde Yansımalı Fiillerin Yapısı. Ankara: TDK Yayınları.

Öztoprak, E. (1995). Benveniste Genel Dilbilim Sorunları. Çeviren: Erdim Öztokat. İstanbul: Yapı Kredi Yayınları.

Rüstemov, R. (1998) Müasir Türk Dilinde Teqlidi Sözler. Bakı: Bakı Universiteti Yayını.

Taylan, A. (2018). Dile Gelen Felsefe. İstanbul: Yapı Kredi Yayınları.

Tekin, T. (1995). Türkmence - Türkçe Sözlük 1. Ankara: Şafak Yayınları.

Zülfikar, H. (1995). Türkçede Ses Yansımalı Kelimeler. Ankara: TDK Yayınları.

KISALTMALAR:

Alm.: Almaca

AzT.: Azerbaycan Türkçesi

DLT.: Dîvânu Lugâti't-Türk

Fr.: Fransizca

GaT.: Gagauz Türkçesi

HorT.: Horasan Türkçesi

İng. İngizce

TrkmT.: Türkmen Türkçesi 